\title{
GLOBALIZATION \& REGIONALIZATION IN INTERNATIONAL TRADE
}

\author{
Ramona Frunză \\ "Alexandru Ioan Cuza" University of Iaşi \\ Liviu George Maha \\ “Alexandru Ioan Cuza" University of Iaşi \\ Claudiu Gabriel Mursa \\ "Alexandru Ioan Cuza" University of Iaşi
}

\begin{abstract}
The concept of globalization refers to the growing interdependence of countries, resulting from the increasing integration of trade, finance, investments, labor markets and ideas in one global marketplace. The most important elements of this process are the international trade and the cross-border investment flows. Economic globalization has increased the specialization of workers, while the companies compete in global markets. Even globalization has recently become a common topic in academic discourse, many economists focused, from the 1980s and 1990s, in addition to globalization, on regionalization - the growth of networks of interdependence within multinational regions of the world. The recent decades are characterized by the fact that the world trade grew faster than world output, which implies that an increasing share of world GDP crosses international borders. The trend is explained, mostly, by the substantially declining of the trade barriers during the same period, as a result of successive trade negotiation rounds under the auspices of the GATT/WTO, unilateral trade liberalization and regional trade agreements. Even there are global connections between all the countries, the strongest political and economic integration is being created within a few specific regions of the world: Europe, North America and East Asia.
\end{abstract}

Keywords: globalization, regionalization, international trade, trade agreement, trade liberalization, economic integration, global market

JEL Classification: F15, F16, F41, F02

\section{OVERVIEW}

Economic interdependences became more frequent in the postwar period, manifesting in a variety of forms that stimulate the adhesion process. In the second report of the Club of Rome, coordinated by the laureate of the Nobel prize for economy, Jan Tinbergen, a series of interdependences are highlighted and it is argued that they are generated by: the need for food, 
energy and minerals, the possibilities of distortion of the ecologic balance, the hope to reduce the considerable differences between the rich and the poor countries. From a generic perspective, globalization expresses the process of expansion of social, economic and political activities across the borders (national, then regional) in such a way that events that occur or decisions that are made in a certain area of the world come to have an impact and influence the lives of people in the other corner of the world. In light of the diversity of views and the absence of agreement on a single definition of globalization, we define it here in a narrow sense to mean the process through which the world's national economies, markets, and businesses are witnessing increasing connectivity. To yet others globalization is seen as a process through which an international, multicultural, borderless, and even information society is being constructed (Nshimbi Christopher Changwe, 2006, p.2)

The globalization, seen as a distinct, unique and unrepeatable process, appeared after the second world war, when:

$\checkmark$ were created the conditions for the polarization of the world in two major sides;

$\checkmark$ appeared a new political world order through the creation of the Organization of the United Nations, which was supposed, via its institutions and agencies, to provide the legal and institutional frame for the preservation of peace and world security, the development of amicable relations between nations and the realization of international cooperation for the purposes of solving international problems with an economic, social, intellectual or humanitarian aspect;

$\checkmark$ the process of decolonization led to the formation of new states in the regions of SubSaharan Africa, Northern Africa and Middle East, South-East Asia and the Pacific.

From our perspective, the end of the Cold War also meant the end of the first stage of contemporary globalization. Firstly, there is no political globalization of the world, based on some universally accepted democratic principles. In this period, the existence of totalitarian states was periodically threatened from the inside, as well as from the outside, the last decade of the Cold War being the ultimate witness of the successful attempts of abolishing dictatorial regimes. We must not forget the fact that there are still states under uni-personal, totalitarian regimes (Cuba, North Korea, the countries dominated by Islamic fundamentalism). Secondly, in the postwar period, we would rather talk (as far as we are concerned, as a continent) of sub-regional or zonal organizations (Council for Mutual Economic Assistance and European Economic Community) that were not the unique voice of the region - Europe, due to its totally opposite ideological principles regarding its formation. Post Cold War globalization registered a considerable level of institutionalization, replacing the rigid and bipolar division of the world with the multi-polarity that expressed itself as 
regionalization. Therefore, we can assume that regionalization and globalization are not opposite, but rather complementary processes. Globalization implies action in very vast, but concretely delineated spaces, enabling common decisions at a regional level. Thirdly, the military globalization registered in that period represented a limited evolution of the system of alliances and a rather predictable structure of international security. The Cold War divided the world under several of its aspects (economic, social and cultural life), but it also reunited it under the form of global military order, called "the equilibrium of terror".

Regionalisation, especially in its de jure forms involving greater or lesser degrees of formal policy integration among governments, emerges as a political response to the challenges of globalisation and at the same time helps to strengthen the microeconomic forces that drive globalisation by stimulating internal competition; significantly enlarging regional markets open to participants; weakening the power of special-interest groups which resist greater competition or attempt to turn regional agreements into bastions of protection; and reestablishing collectively, among participants, policy sovereignty vis-à-vis internal and global markets (Oman Charles, 1994, p.4).

Regionalization is the realization of some regional trade arrangements with various degrees of adhesion. Two values of regional integration can be identified for the postwar period: beginning with the 50s, there were numerous attempts to create some free trade areas or common markets in Europe, Africa, Latin America, the Caribbean Islands and Asia. Except for Europe, the attempts of regional integration of the first wave failed. The regionalism of the second wave is a phenomenon of the 90s. It is vaster than the first wave and it may have been provoked by the increasing international interdependence and the progress in the field of communications. The second wave consists in the attempts to create regional trade agreements, customs associations, customs unions and common markets.

\section{GLOBALIZATION AND THE REGIONAL SUCCESS}

Although regionalization (the division in regions) is widely spread in the territorial organization of European countries, it is impossible to define a common fundamental concept for all existing regions. In some countries like, for example, Italy, the regions immediately became functional, in other countries they serve as a means of actions of economic nature for the central government. This was the case of France and Great Britain. The reforms of the reform attempts (in Belgium, Spain, France and Portugal) in the period of the 70s transformed regionalization in the main topic of political debates. Many states do not recognize the region as a new level of the 
government; other states differ from the standpoint of the nature and role of the region, having various elaborated concepts about the region. The regionalization of the new member states and of the states that will adhere in the future contributed to the diversification of the term region. This is why there is a tendency to hesitate between two fundamentally opposed and equally inappropriate concepts. The first concept is based on a purely descriptive definition: the region is the entity situated immediately under the level of central government, with a political power of representation, via the selected board. The second concept is based on the representation of the region via an association or institution created at a regional level by the immediately inferior authorities (as is defined in the statute of the Reunion of European Regions).

The newest initiative in the regional politic domain is represented by the Communication of the Commission from July 2003, reffering to the creation of a new instrument of promoting of the sustainable economic and social development. It is about the „Neighbourhood Instrument”, which appears as a consequence of the extending process of EU and reflects the interest for the Union border change. This new instrument is based on the existing experience in promoting the crossborder cooperation, acumulated by Phare, Tacis and Interreg programs, and will be centred on the assurance of the well functioning and a good management of the future borders in East, with the purpose of development of the border regions.

This instrument can also contribute to the promovation of stability and prosperity inside and outside the Union borders.

The objectives considered by this instrument are:

- Promoting of economic and social development in the border regions;

- The cooperation for treating the common needs, in fields like: environment protection, public health, fighting against the organised crime;

- The assurance of safe and efficient borders;

- The promoting of local actions - „man to man”.

The factors that are taken into consideration for the strengthening of a system of functional regions, of potential success, and those for the development of regions are: historical factors, related to tradition; cultural factors; the geographical factor (natural homogeneousness and the connection with the state borders); the adequate dimension for real and efficient socio-economic activities; a number of center of development/potential growth (city which are likely to develop with a bidirectional socio-economic dynamics in relation to the marginal area). Also, there are the market factors, cost factors, governamental factors and competitiveness factors. 
Table 1 - Determinants of globalization

\begin{tabular}{|c|c|c|c|}
\hline Market factors & \multicolumn{2}{|c|}{ Cost factors } & Governamental factors \\
\hline $\begin{array}{l}\text { - The convergence of revenue per } \\
\text { capita in industrialized countries; } \\
\text { - The convergence of life styles; } \\
\text { - The increasing mobility - global } \\
\text { consumers; } \\
\text { - The development of marketing; } \\
\text { and of distribution channels at } \\
\text { global/regional level; }\end{array}$ & \multicolumn{2}{|c|}{$\begin{array}{l}\text { - Scale economies; } \\
\text { - Technological innovation; } \\
\text { - Progresses in transport } \\
\text { systems; } \\
\text { - The apparition of new } \\
\text { economic forces; } \\
\text { - The increasement of the } \\
\text { development costs versus life } \\
\text { duration; }\end{array}$} & $\begin{array}{l}\text { - The reduction of the } \\
\text { taxation barriers; } \\
\text { - The reduction of the } \\
\text { non-taxation barriers; } \\
\text { - Commercial trusts; } \\
\text { - The decline of the } \\
\text { government role as } \\
\text { producers/clients; } \\
\text { - The privatization; }\end{array}$ \\
\hline \multicolumn{2}{|l|}{ Competitiveness factors } & \multicolumn{2}{|l|}{ Other factors } \\
\hline $\begin{array}{l}\text { - The intensification of the } \\
\text { commerce; } \\
\text { - The increasing number of strategic } \\
\text { - The rise of imports; } \\
\text { - The apparition of new actors de } \\
\text { become global competitors; } \\
\text { - The development of global networ } \\
\text { determine interdependence between } \\
\text { certain industries; } \\
\text { - The apparition of the global } \\
\text { alliances; }\end{array}$ & $\begin{array}{l}\text { mondial } \\
\text { narkets } \\
\text { cided to } \\
\text { ks which } \\
\text { states in } \\
\text { strategic }\end{array}$ & $\begin{array}{l}\text { - IT revolution; } \\
\text { - The globalization of } \\
\text { - Increasing business }\end{array}$ & $\begin{array}{l}\text { the financial markets; } \\
\text { raveling. }\end{array}$ \\
\hline
\end{tabular}

Research performed by well-known experts (for example, Dunford and Hudson) show that the government decentralization in regions is not enough to guarantee economic success. They discovered that the prosperous EU regions:

- display a high level of social cohesion and participation ;

- achieve relations of cooperation in the field of industry, which are illustrative of their flexibility and security

- have cooperation at the level of the companies, including a network of cooperation

- "incorporate" internal investments, which have a considerable added value in the regional economy 
- adopt strategies in order to augment innovations and the technological transfer

- have government institutions, which have "learned to learn"

- maximize the potential of trans-border synergies

- manifest a vibrant, state accepted civil society

\section{Figure 1}

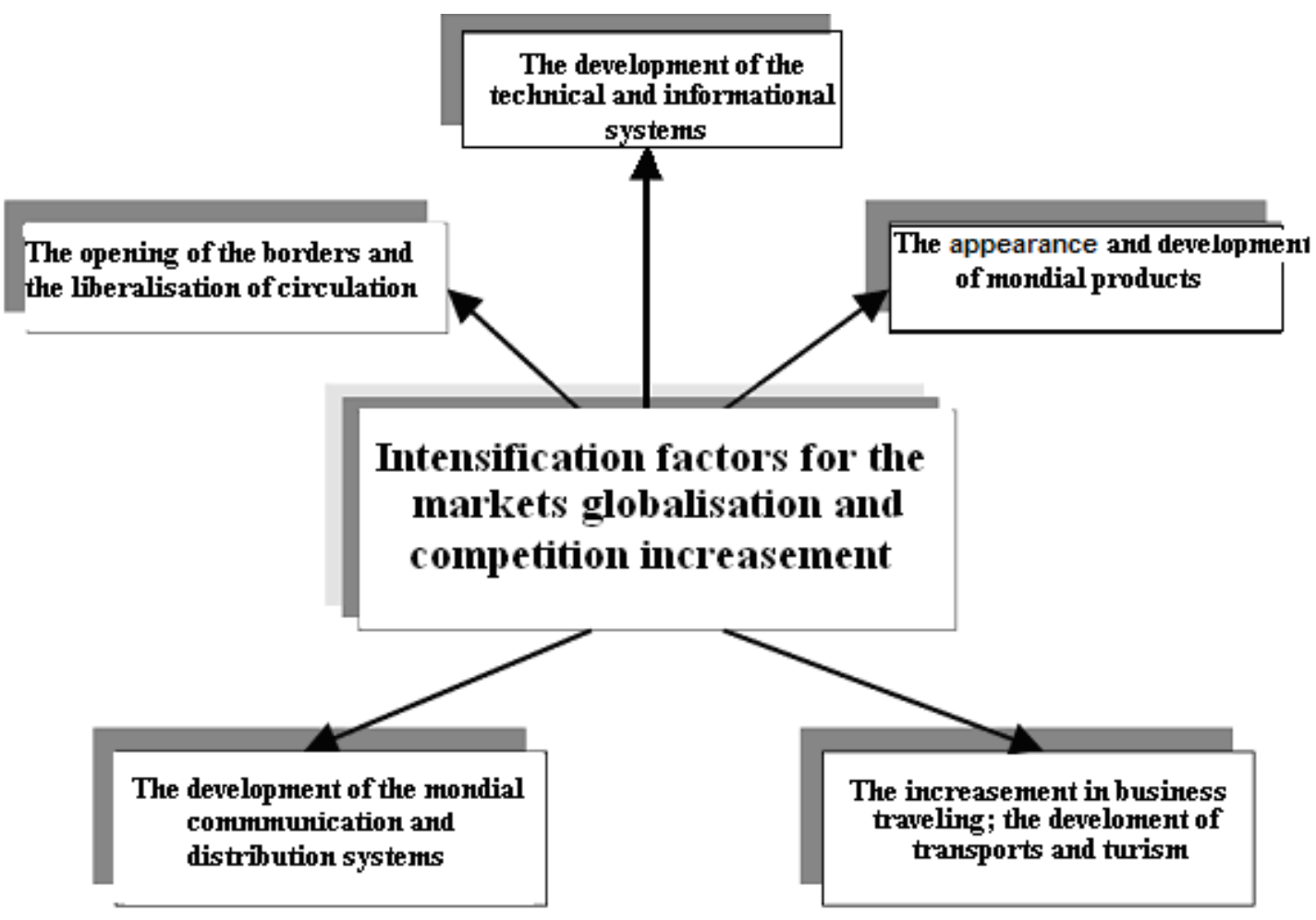

Source: Brilman J., 1990, p.26

\section{THE CONSEQUENCES OF REGIONALIZATION \& GLOBALIZATION AT EUROPEAN LEVEL}

In many of the European regions with economic success, social cohesion and participation appear as imperative conditions for economic success. The symbiotic relationship between cohesion and success manifests itself in multiple ways, and many of them can be resumed as culture of commitment, which gravitates around a variety of relations based on cooperation and trust. It is also true that in some successful regions of Western Europe, the character of social inclusion is obviously problematic - for example, many workers in the successful regions in Germany are international migrants, with no citizen rights. This suggests the fact that economic success can be, in some circumstances, dependent on the partial and selective opinions concerning cohesion. Many of 
the successful European regions are characterized by particular forms of relations between companies, which highlight cooperation, trust and network communication. Often, these networks have the specific character of the place, as is the case of the industrial areas of interconnected small and medium enterprises. Many small enterprises are dynamic and rely on innovative design, order based production and quality, in order to be able to remain competitive. Network connection, based on mutual trust, enables these companies to successfully adopt competitive strategies. Cooperation networks facilitate training, innovation, the spreading of knowledge and the creation of specific territorial types of knowledge, essential for competitiveness. There are ,however, significant differences between these regions, where "the horizontal" networks of SMEs are the main advantage of the corporate picture (as is the case with the North-East and center of Italy) and those dominated by major companies ( such as Baden-Württemberg). The relations of cooperation between companies are centered on formal agreements, often complementary to the realization of some performance objectives and less to a non-formal relation of trust. Nevertheless, the network collaboration relations of large companies are at least partially transnational. Thus, this means that "old" industries that exist in poor economic regions of Europe can become a basis for future growth, if the appropriate organizational structures evolve. The globalization process and the marketing approach of investments launched a new modality of "investments in companies that are representative for a particular branch" in the marginal regions of the European Union, thus enabling an economic activity with a greater added value and a tighter connection with economy and the regional capacity. These schemes introduce, via the constitution of a "supply network", a better diversification of market risks (by abandoning market segments). Such a "quality" of attracted investments can create an important number of new workplaces, and may have many other positive effects on regional economy, even if it is necessary to emphasize the fact that investments in companies belonging to this branch in the marginal regions of Europe will lead to the utilization of the unqualified workforce for mass production. No one can deny the fact that the success of a region depends on the government system and on the pro-active approach of local governments in the socio-economic field, authorizing and facilitating the appearance of institutions, forming partnerships with the civil society and the business community. These mechanisms enable the elimination of borders and support the formation and the development of local/regional economies. The governmental structures of the state should be ware of the fact that national economy is rooted in regional/local economy and the regional/local models of development are, usually, incorporated in successful national economies. 


\section{THE DIFFERENCE BETWEEN GLOBALIZATION AND REGIONALIZATION}

It consists in the fact that, in the case of regionalization, liberalization occurs on a smaller scale, geographically limited to the space of the states that participate in the grouping. Economic data highlight the fact that the volume of inter-regional trade increases as fast as that of intranational trade, which proves that regionalization is an integral part of globalization. Poorly developed countries advocate the idea of regional integration, arguing that its practical realization represent the way towards industrialization, the liquidation of economic regress and the expansion of the connections between the countries in the integrated areas. In this respect, one of the deputies of the general manager of the International Monetary Fund, Alassane D. Quattara, states that regional integration constitutes an important step towards global integration: "developing countries cannot escape globalization and should not try to avoid it". Trade played a significant part in the globalization process, since the expansion of manufacturing in industrialized countries was due to the accentuated interpenetration of national economies, to a large extent by means of intra-branch trade, in such a way that global markets evolved in relation to processed products, as well as in relation to their inputs. The increase of trade between developed and developing countries, in the 80 s, also reflected a change in the nature of production. Thus, a new international labor division was formed. Markets tend to become global due to the fact that internal markets are no longer capable to bear the increasing costs of research and development and the shorter and shorter lifecycles of the products, from a technological perspective. In an increasingly accentuated modality, large corporations are expanding their scope outside their national borders, resorting to transnational management in the field of innovation, manufacturing and trade. A genuine network of ,strategic alliances”, such as: company merger, creation of mixed societies, etc., enables corporations to share the inherent risk of developing products for international markets and the benefits resulted following the expansion of portfolio investments realized based on these products.

\section{IMPORT AND EXPORT ON THE GLOBAL MARKET}

A global market requires the existence of some significant levels of regulated exchanges of goods and services at an interregional scale. Where the obstacles which prevent trade, be they transportation costs or protectionist measures, registered a considerable decrease, foreign producers from a certain region can compete with domestic producers from another region. The dynamics of international trade is very strong. It attracts the globalization of industry, under the influence of two 
processes. On one hand, the enterprises seek to conquer new markets, and this makes them stay as close as possible to potential customers. This is the attitude of big international companies. On the other hand, many enterprises are compelled to delocalize part of its production in order to reduce the cost of the workforce. Thus, electronic produces most of its primary devices in South-East Asia. The revolution in the field of communications enabled many big international companies, known as transnational corporations, to decentralize their manufacturing process. They are now capable of to locate their research and development where most scientists are available. Truly new is the growth of global trade in the second half of the twentieth century. Many countries limited their restrictions imposed on international trade and trans-borders circulation of goods expanded considerably. Trade developed in a rhythm twice faster than that of global production. A vast opening of economies towards the exterior was initiated. Between 1955 and 1975, Europe especially and then the world economy, as a whole, registered the longest postwar boom, when the increase of the volume of trade was associated with the strengthening of the position of multinational corporations situated on the territory of Europe, the United States of America and, to a smaller extent, Japan.

In a globalised world, Europe's trade policy must become an integral part of its wider approach to economic reform and competitiveness. A stronger EU economy at home means Europe has to be more competitive abroad. We need to open markets and create new opportunities for trade and ensure European companies are able to compete fairly in those markets. EU trade policy aims to contribute to a more equitable integration of developing countries into the international trading system through coherent action on three levels: the multilateral (which remains the key area of EU trade policy), the bilateral and through autonomous measures.

In the following graphics we compare the exportation and importation in the period 20002006 in the main regions of the world. 
Graphic 1 - Merchandise export

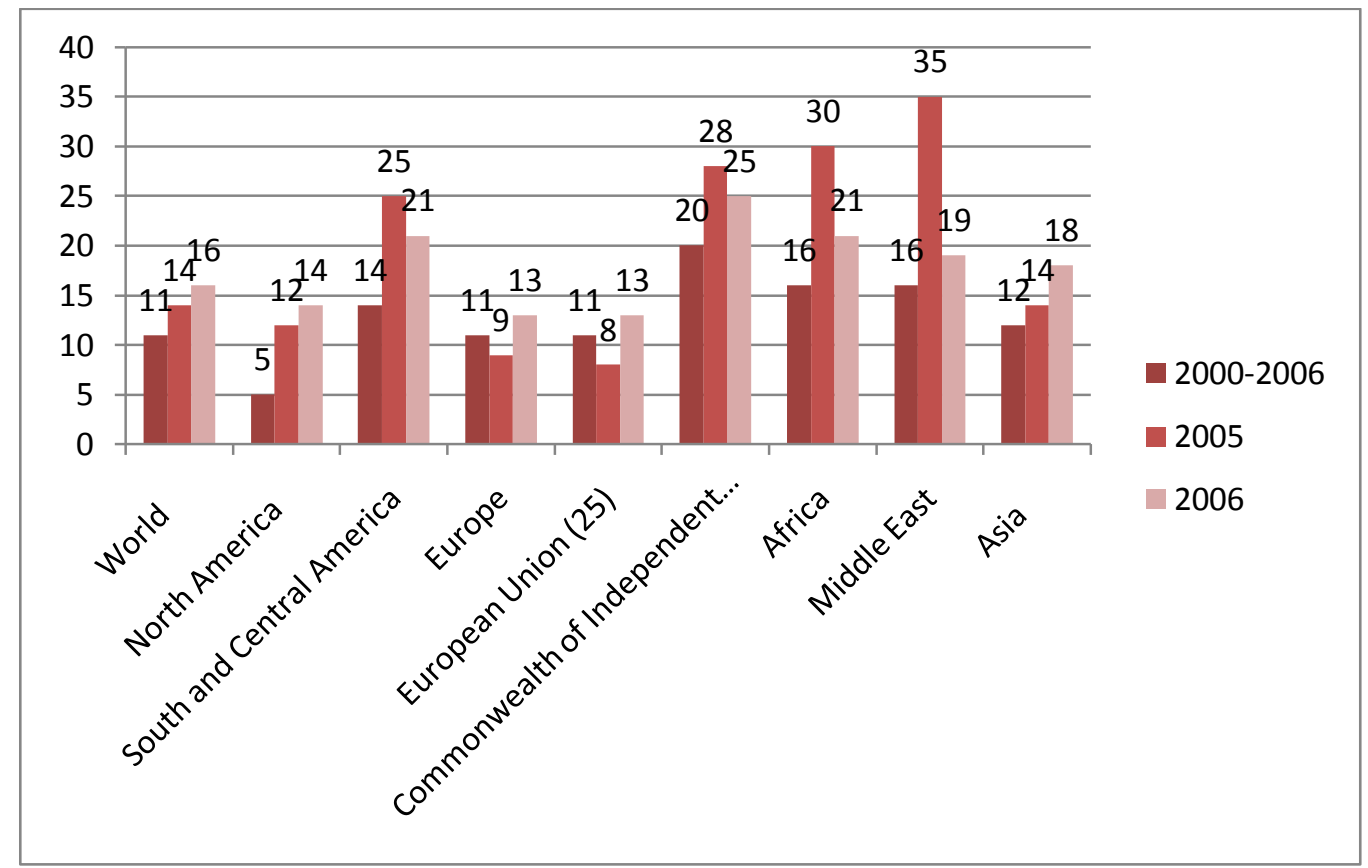

Source: www.wto.org

The global exportation of goods and services tripled in the period 1992-2006. In graphic 1 we considered the merchandise export of the main regions of the world in 2000-2006. At present, about $20 \%$ of the global production is traded and a much higher percentage constitutes, potentially, the object of international competition: commercial activities reached an unprecedented level as an absolute value, as well as in relation to global production. The structure of world trade in relation to various types of commodities differed considerably in the last decades. The main tendency was that of increase of the percentage of manufactured goods and services from the total of global exports. The percentage of primary products, offered especially to the poorest countries, registered a decrease. 
Graphic 2 - Merchandise import

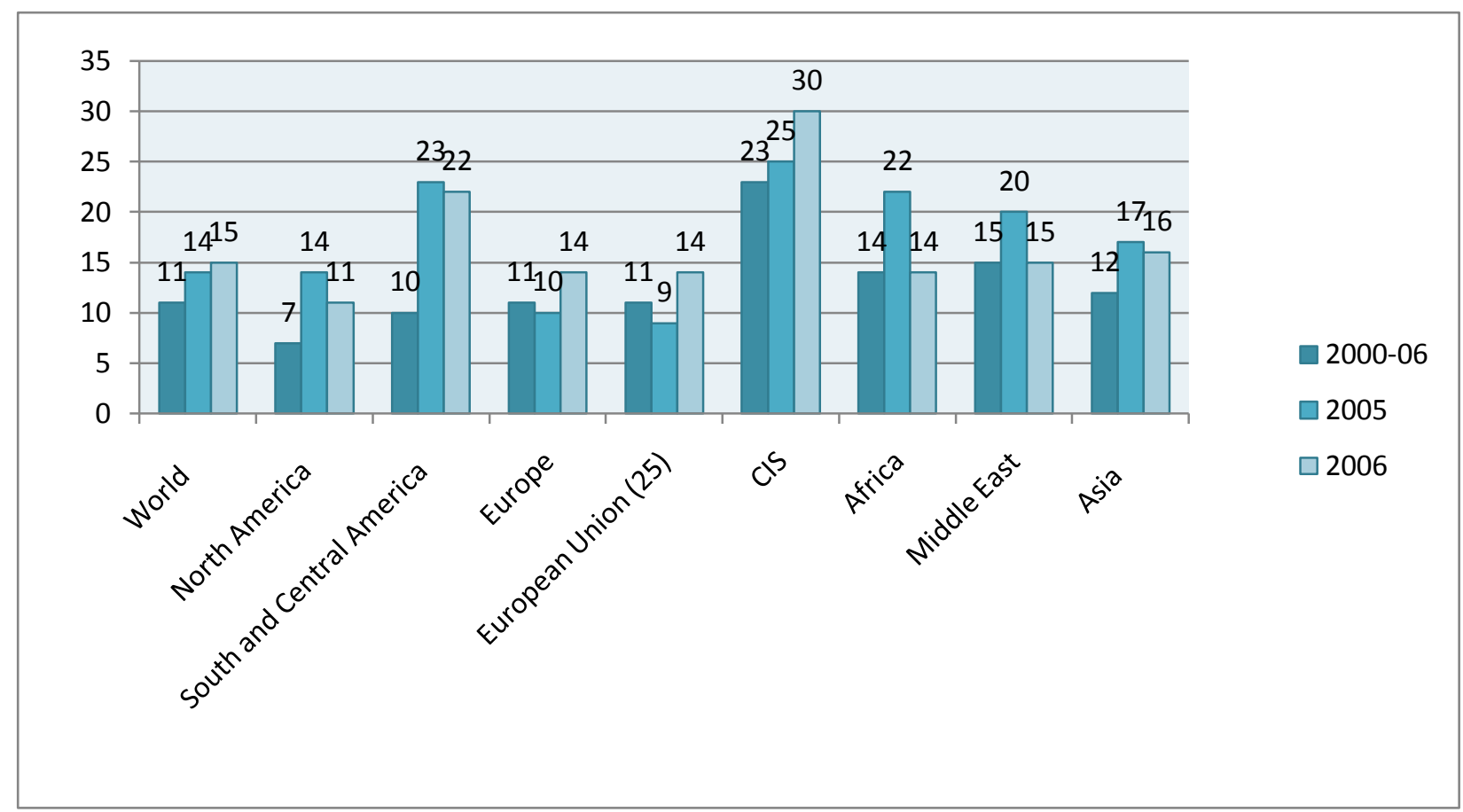

Source: www.wto.org

The analysis of the geographical distribution of the importation and exportation of products confirms the existence of three global poles: North America, Western Europe and South-East Asia, which cover, taken together, two thirds of world trade. The great industrialized countries are at the same time the biggest importers and exporters in the world, the United States of America being the undisputed leader. A series of relatively small countries, especially from Asia, states considered developing countries, registered great economic transformations in the last three decades, due to their focus on exportation. In these cases, international trade functioned as a genuine vehicle or as the main promoter of economic development. The recently industrialized countries in Asia registered positive evolutions, whereas Africa, as a whole, had a declining trend.

In the section bellow we present the situation concerning the commercial services in exportation and importation. 


\section{Graphic 3 - Commercial services - exports}

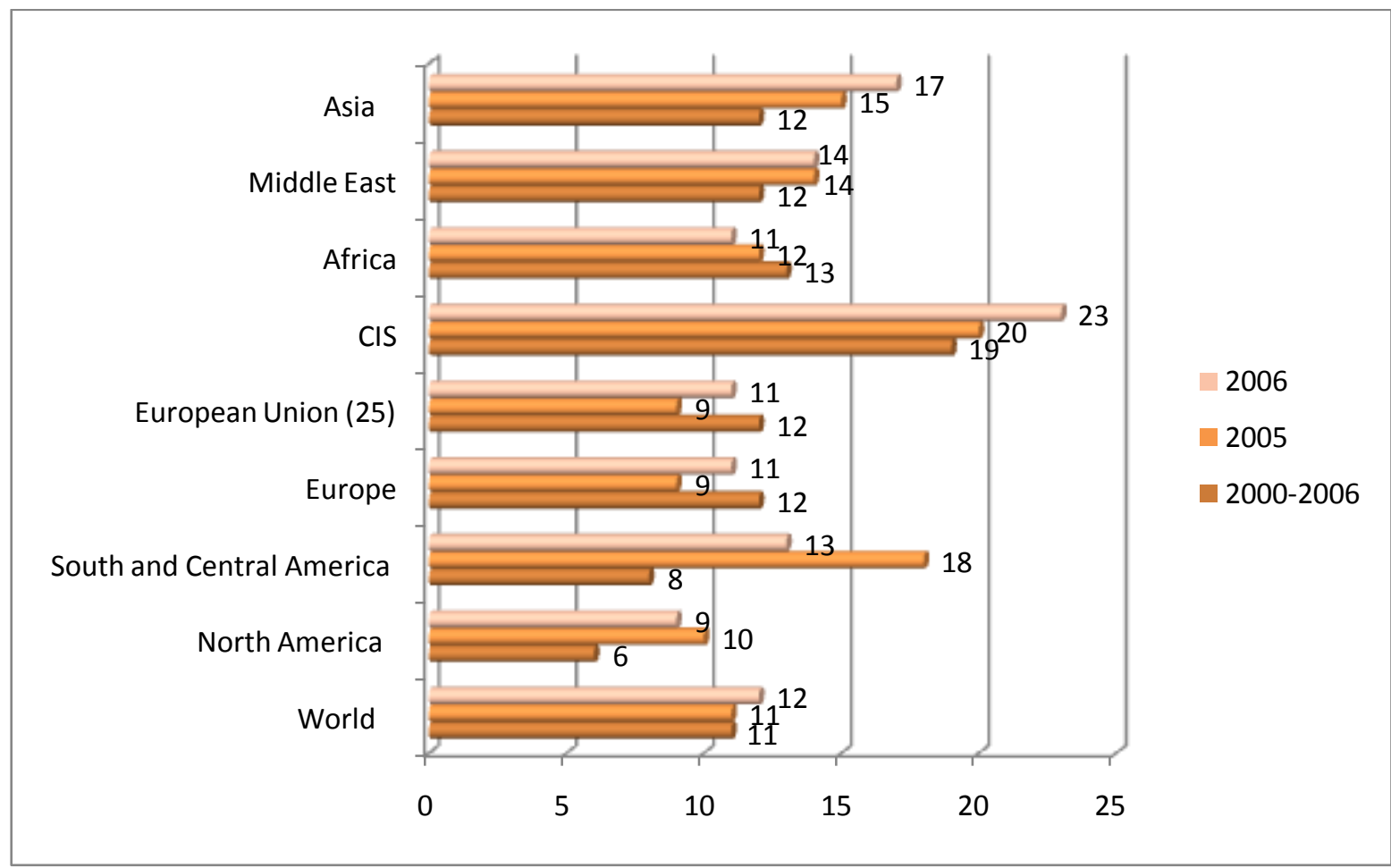

Source: www.wto.org

Merchandise trade expansion and quality improvement, intra-regional trade expansion, easier and cost-effective access to international capital, technology and professional manpower markets, expanding business opportunities overseas, enhanced international flows of people, information, knowledge and ideas, leading to the concept of a global village represent the positive impact of globalization (Hirono Ryokichi, 2006). 
Graphic 4 - Commercial services - imports

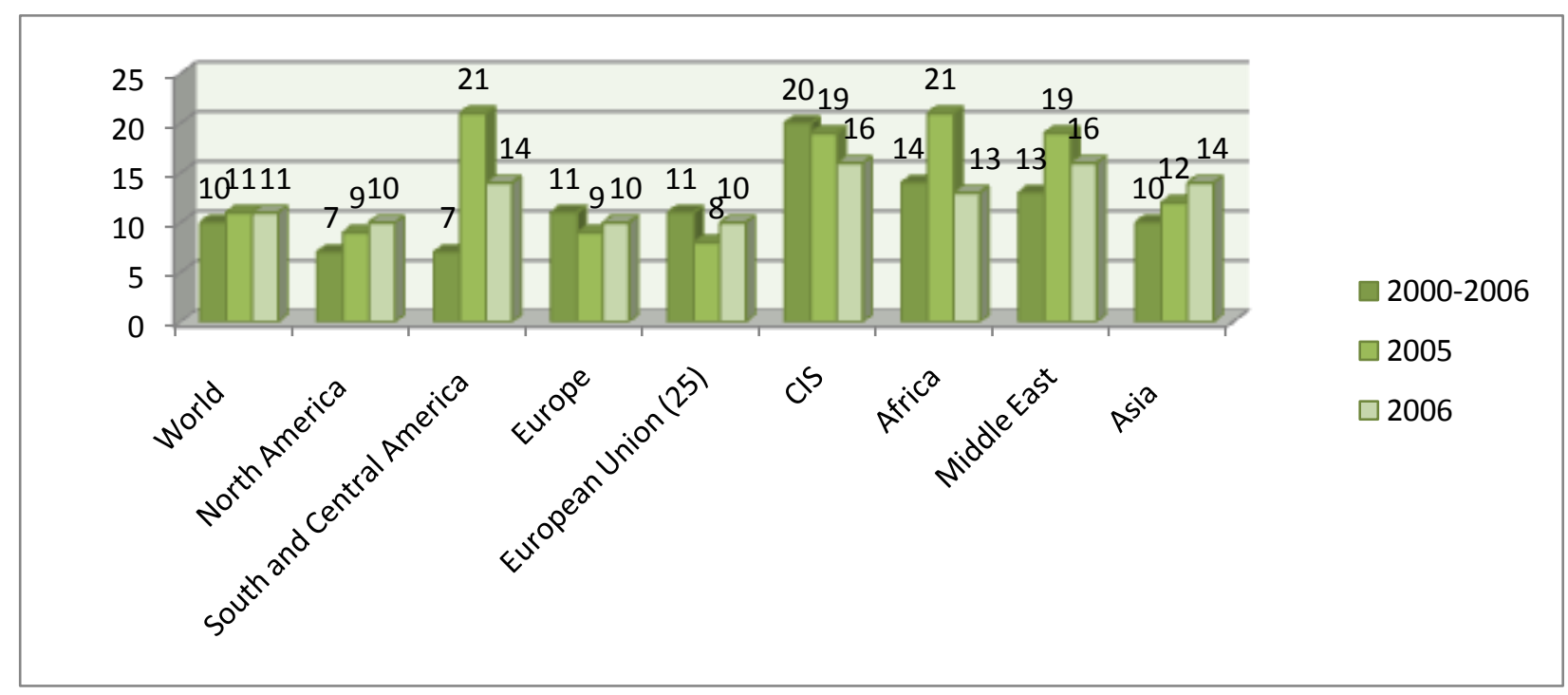

Source: www.wto.org

The World Bank estimated that a pro-poor outcome of the current Doha Development Agenda could increase global income by up to $€ 300$ bn, with half accruing to developing countries. However, the world's poorest countries have not always been able to fully benefit from the trade opportunities offered by the multilateral trading system.

Briefly, The World Bank has characterized the activities of importation/exportations of EU in the following terms:

- EU imports from developing countries have continued to rise. They increased by $16 \%$ between 2005 and 2006 and by 14\% if China is excluded. Imports from developing countries with which the EU has Free Trade Agreements have also shown a healthy rise between 2005 and 2006: from Mexico 15\%, from South Africa 10\% and from Chile 54\%.

- Almost $70 \%$ of imports from developing countries entered the EU at a zero tariff rate in 2006. This was the case for almost $98 \%$ of imports from the African, Caribbean and Pacific countries (this figure will now increase because the signing of the Economic Partnership Agreements has further extended duty-free treatment for ACP countries). 88.5\% of Least Developed Country imports to the EU entered at a zero tariff rate.

- Agricultural exports from developing countries to the EU grew by just under $12 \%$ from 2005-2006. Textiles imports grew by $12.3 \%$ for the same period.

- EU imports from the 50 Least Developed Countries (LDC) increased by just under 7\% 2005-2006. The biggest increases in LDC exports to the EU were in textiles, which grew by $25 \%$. 


\section{CONCLUDING REMARKS}

The globalisation imposes to Europe different challenges: the demographic deficit, the reduction of the active population, the necessity of adaptation to the climatic change and the armonisation with the technological change etc. The main issue is to face the inequalities determined by the globalisation. The life long learning, the mobility, the social dialog, the anticipation of the new needs, the flexibility, but also the keeping of the social protection are some answers for the new challenges. The European Union has a financial mechanism which follows the equilibration of the negative effects of the globalization - sharper distinction between winners and losers at the international levels including greater disparities among both industrial and developing countries, a higher external dependence, global warming and environmental destruction, globalization of unsustainable patterns of production and consumption, reduction/loss of cultural diversity, and rise of ill-directed nationalism and patriotism, leading to international terrorism and the possibility of greater international conflicts - named The European Globalisation Adjustment Found.

\section{REFERENCES}

Archibugi, D., Lundvall, B.A. (2001), The Globalization Learning Economy, Oxford University Press, Oxford.

Canavero Alfredo et. al. (2000), Globalisation, Regionalisation and The History of International Relations, International Committee of Historical Sciences (C.I.S.H.), Commission Of History Of International Relations, Milan.

Chia, S. Y. (1997), Regionalism and Subregionalism in ASEAN: The Free Trade Area and Growth Triangle Models, in Ito, T., Krueger, A. O. (eds.), Regionalism versus Multilateral Trade Arrangements, Chicago: The University of Chicago Press, pp. 275305.

Friedman, L. Th. (2005), The World Is Flat. A Brief History of the Twenty-first Century, Farrar, Straus and Giroux, New York.

Garton Ash, T. (2004), Free World. America, Europe and the Surprising Future of the West, Random House, New York. 
Giddens, A. (2000), Runaway World: How Globalization is Reshaping our Lives, Routledge, New York.

Held, D., McGrew, A. (2002), Governing Globalization: Power Authority and Global Governance, Polity Press, Cambridge.

Held, D. et al. (1999), Global Transformation: Politics, Economics and Culture, Stanford University Press, Stanford.

Hettne, B., Sunkel, O. (1999), Globalism and the New Regionalism, MacMillan Press Ltd, London.

Ryokichi, H. (2006), Globalization, Regionalisation and Choices Facing Asia, Seikei University, Tokyo.

Masson, P. (2001), Globalization: Facts and Figures, IMF policy Discussion Paper PDP/01/04, IMF, Washington.

Moore, M. (2000), Trade, Poverty and The Human Face of Globalization, Reuters/Carnegie Public Policy Series - London School of Economics WTO speeches DG Mike Moore

Changwe, N.C. (2006), Threatened with Marginalization: is Regionalization the Appropriate Strategic Response to Globalization?, The Third CEPII-IDB Conference New Regionalism: Progress, Setbacks and Challenges, Washington.

Oman, C. (1996), The policy challenges of globalisation and regionalisation, OECD Development Centre, Policy Brief, No. 11.

Oman, C. (1994), Globalisation and Regionalisation: The Challenge for Developing Countries, OECD Development Centre, Paris.

Rodrik, D. (1997), Has Globalization Gone Too Far?, Institute for International Economics, Washington.

Weber, S. (2001), Globalization and the European Political Economy, Columbia University Press, New York.

International Monetary Fund, IMF. (2000). Globalization: Threat or Opportunity? Available on the World Wide Web: <http://www.imf.org/external/np/exr/ib/2000/041200.htm>: Retrieved January 5, 2006.

www.wto.org. 